\title{
Salt Tectonics in the Southern Iran
}

\author{
Azar Khodabakhshnezhad1, Mehran Arian2* \\ ${ }^{1}$ Department of Education, One Territory of Baharestan Education Office, Ministry of Education, Tehran, Iran \\ ${ }^{2}$ Department of Geology, Science and Research Branch, Islamic Azad University, Tehran, Iran \\ Email: *mehranarian@yahoo.com
}

Received 25 January 2016; accepted 25 March 2016; published 28 March 2016

Copyright (C) 2016 by authors and Scientific Research Publishing Inc.

This work is licensed under the Creative Commons Attribution International License (CC BY).

http://creativecommons.org/licenses/by/4.0/

(c) (i) 0 pen Access

\section{Abstract}

Based on geographic distribution and geological setting of salt plugs in southern Iran, three salt diapiric provinces have been distinguished. These provinces include the Hormuz, Shiraz-Kazerun and Nyriz-Jahrum sub-basins. There are more than hundred salt plugs which they have been formed and developed in the southern margin of Iran. The salt structures that originated from Hormuz formation in these areas have been restricted and separated from each other for the first time in this paper. Salt diapirism of these provinces has been triggered earlier by Halokinesis in the Zagros and Persian Gulf basins, but it has affected later by tectonic forces, because orientation, shape and position of salt plugs have been followed from convergence regime (especially in the Zagros hinterland). In the other hand, based on our results from salt plugs in Persian Gulf foreland basin and the Zagros hinterland, Halokinesis triggers has been affected more than Halotectonic forces.

\section{Keywords}

Salt, Tectonics, Zagros, Persian Gulf, Iran

\section{Introduction}

The purpose of this research is clustering of salt plugs in the southern margin of Iran such as central Iran that it has worked by [1] [2]. The southern margin of Iran is including the Zagros orogeny belt and Persian Gulf [3].

The structural trends in Zagros province are north west-south east. It contains the fold and thrust belt that formed on the northeastern margin of Arabian plate [4]. Zagros Mountains have been terminated to the north of Minab city in Iran. Zagros hinterland is external platform of Arabian plate, from tectonics point of view. This mountain range is results of collision between Arabian and Cimmerian plates and thus it can be consider as an orogenic belt.

\footnotetext{
${ }^{*}$ Corresponding author.
} 
More than 100 emergent salt structures, up to now, have been recognized in the Zagros mountain and Persian Gulf areas [5]-[7]. The most of emergent these salt structures are related to central and eastern part Zagros and Persian Gulf areas.

\section{Materials and Methods}

Hormuz Salt had been deposited within N-S and NW-SE trending troughs of the Arabian Basement in Late Precambrian-Early Cambrian. Also, Presence of Hormuz Salt in the western part of the Zagros Belt including the Abadan Plain is almost possible by geophysical data. Analysis of gravity data denotes negative anomalies beneath the structural highs. Also, seismic data are presenting additional evidences for upward movement of the Hormuz Salt which affected deposition of the younger sediments. Anticline structures of the Abadan Plain are formed above strike-slip fault systems. Salt walls or salt anticlines are probably emplacing core of the N-S trending structures. Upward movement of salt is due to curvature and step over along the strike-slip fault system and transtension [8].

The name of the Hormuz salt was taken from the Iranian Hormuz Island, cored by a salt diapir, which also gives its name to the opening strait of the Persian Gulf. The Hormuz formation [9] consists of 4 members and it is including salt, anhydrite, shale, siltstone, dolomite, sandstone, banded Hematite and volcanic blocks which are an evidence for volcanogenic genesis of salt formation model [10]. The Hormuz and equivalent series were deposited in an evaporate basin during the late Precambrian-early Cambrian [11].

Coeval salt basins crop out in a large domain including the eastern Zagros, Persian Gulf, Oman, Qatar, Central Iran, Pakistan, and northwest India [12]. Hormuz salt is supposed to be absent along the north-south trending Arabian arches, inherited from Pan African structures. Its initial thickness remains highly speculative: 900 $1500 \mathrm{~m}$ for [13], $1500 \mathrm{~m}$ for [14], and 2000 - $4000 \mathrm{~m}$ for [15]. In the Fars domain of the eastern Zagros, this basal formation is covered by 7 to $9 \mathrm{~km}$ of sedimentary rocks [16].

The age of salt diapirism of Hormuz in the Zagros orogeny belt is very different and it has investigated by many workers such as [17]-[19]. Firstly, [20] suggested that most of the salt diapirs are pre-orogenic, and possibly had a prominent role in determining the location of folds during the Neogene Zagros orogeny.

This condition has confirmed by later researches such as [21]-[23]. Also, [24] proposed that the initiation of salt movement in Persian Gulf began during the Permian [25].

\subsection{Tectonic History}

The Zagros orogenic belt is a result of the Neogene collision between the Arabian and Cimmerian plates [26][28]. Tectonic column of the Zagros can be divided into at least, five tectonic stages [29] that existed between orogenic event at late Proterozoic (Pan-African), early rifting (intense chasmic in continental condition) event at Infra-Cambrian, late rifting event (quiet chasmic in marine condition) at Triassic and orogenic event at Neogene, that is related to continental collision.

The sedimentary succession in the Zagros is 6 - $18 \mathrm{~km}$ thick and ranges in age from Infra-Cambrian to Recent. There is a break up unconformity (the absence of Silurian and Carboniferous sediments) that is appropriate with [30] model for Passive margins evolution. Break up unconformity is coinciding with ocean floor spreading and sea transgression.

The northeastern part of Afro-Arabian plate margin began to undergo regional extension in the Infra-Cambrian to Carboniferous, finally caused to appear of a narrow oceanic basin between the Afro-Arabian plate and Cimmerian miniplate (Neo-Tethys) from the Carboniferous.

Then, post-rifting facies of passive margin from early Permian to the late Cretaceous were deposited on the Zagros basin. Since the late Jurassic, the Neo-Tethys ocean began subduction under the Cimmerian miniplate. A proforeland basin [31] formed at the NE margin of the Afro-Arabian plate from the Late Cretaceous, which it was accompanied to emplacement of Ophiolite rocks [32] [33]. The folding and regional uplifting of Zagros proforeland basin occurred at the end of Early Miocene. Therefore, Zagros is an active fold and thrust belt [34] same to Central Iran [35]-[38] and Alborz [39]-[43].

\subsection{Geographical Position of Salt Structures}

Salt diapirs of Zagros present a large variety of shapes and elevation from high relief to entirely eroded struc- 
tures. In addition, they have different sizes at outcrop scale, ranging from craters a few km wide to diapirs and glaciers more than $5 \mathrm{~km}$ wide. These different morphologies are controlled by various factors, for example, position related to other structures, the time of emergence, the rate of salt dissolution, which is controlled by the rate of erosion, the bulk rate of salt emission from the source layer, and eventually by the tectonic activity [16].

The Salt plugs of the southern Iran can be divided into four areas, based on geographic distribution and geological setting of salt plugs (Figure 1):

1) The first area is central Zagros, with 23 emergent salt plugs.

2) The second area is southeastern part of Zagros, with 84 emergent salt plugs.

3) The third area is north margin of Persian Gulf, with 10 emergent salt plugs such as Hormuz, Larak and Abu Musa Islands.

4) The fourth area is an area between the first and second region in Zagros, with many subsurface salt plugs.

\section{Results and Discussion}

There are three diapiric provinces have distinguished (Figure 1).

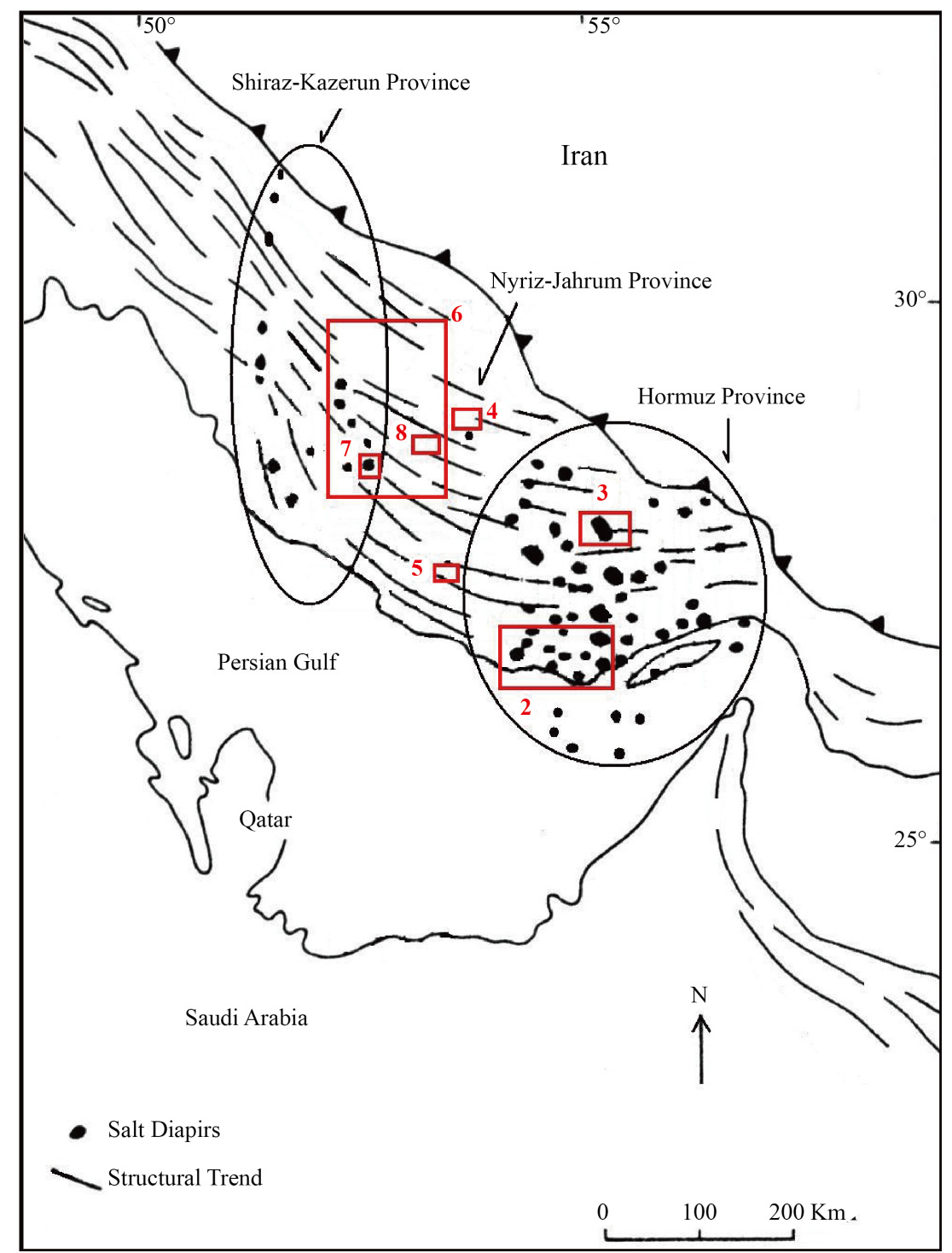

Figure 1. Geographical distribution of three diapiric provinces in Zagros. Locations of figures 2 - 8 are shown by red rectangles. 


\subsection{The Diapiric Province of Hormuz}

The diapiric province of Hormuz, in the east end of Zagros, with eighty four exposed salt diapirs is the widespread salt depotrough in Zagros. Because, based on previous studies, such as [16], there are six type salt diapirs by investigation of the present-day surface morphology of them. They believe that nearly all the diapirs of the study area were already active prior to Zagros folding either as emergent diapirs forming islands in the Paleogene to Neogene Sea or as buried domes initiated at least by the Permian. They have been reactivated by subsequent tectonic events [44].

Therefore, only some of salt diapirs have been exposed in post-orogenic phase, and their shape and location have controlled by folds and faults interactions during orogeny (Figure 2). So, the most of salt domes on this province are pre-orogenic diapirs. Also, big salt glacier such as Mazijan salt dome with a very clear salt Fountain (Figure 3) is a general phenomenon in Hormuz diapiric province [44].

\subsection{The Diapiric Province of Nyriz-Jahrum}

The diapiric province of Nyriz-Jahrum, in the centrral Zagros is a small salt minibasin. It has got a few exposed salt diapirs, many blind domes such as Sim, Meymand, Bavush, Kharman (Figure 4), Kuh-e Gavbast anticline (Figure 5) and diapiric fold such as Kuh-e Bavush (Figure 5) that located on the west part of Hormuz diapiric province.

The Gavbandi High [33] has been formed the south termination of Nyriz-Jahrum province. The Gavbandi High has been formed by regional uplifting of northward continuation of the Qatar Arc towards Iran, during the Late Pre Cambrian - Early Cambrian. Therefore, there are not thick evaporate layer.

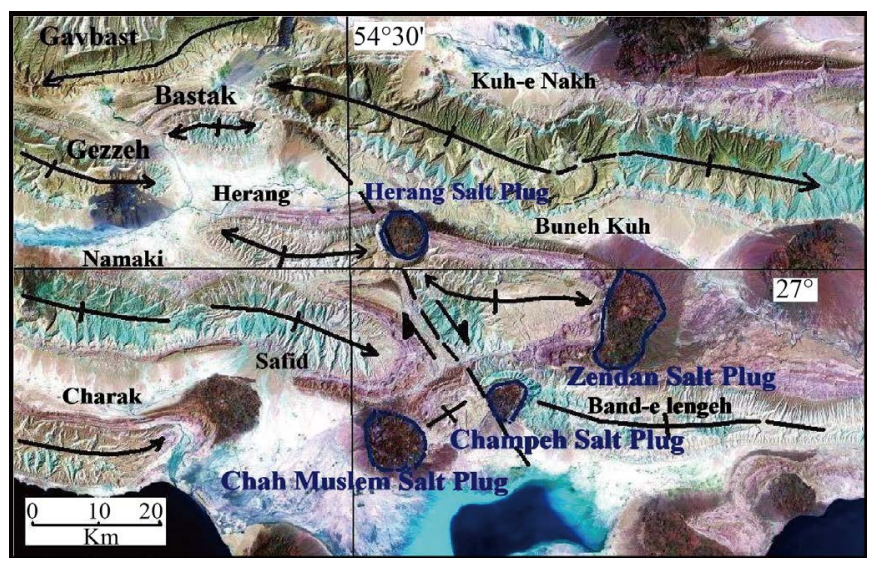

Figure 2. Interpreted ETM+ Satellite Image of salt diapirs and other structures in a part of Hormuz province. Map located in Figure 1.

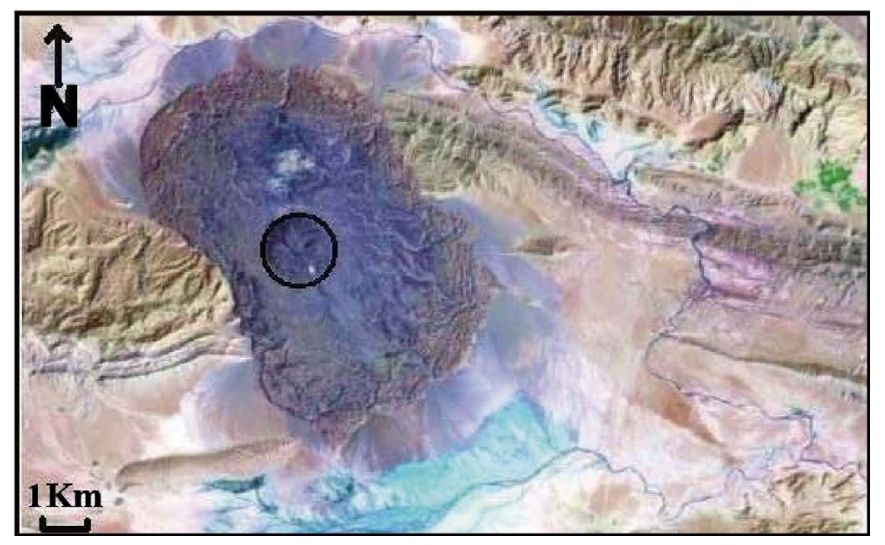

Figure 3. Interpreted ETM+ Satellite Image of Mazijan salt dome with a very clear salt Fountain (Black circle). Map located in Figure 1. 


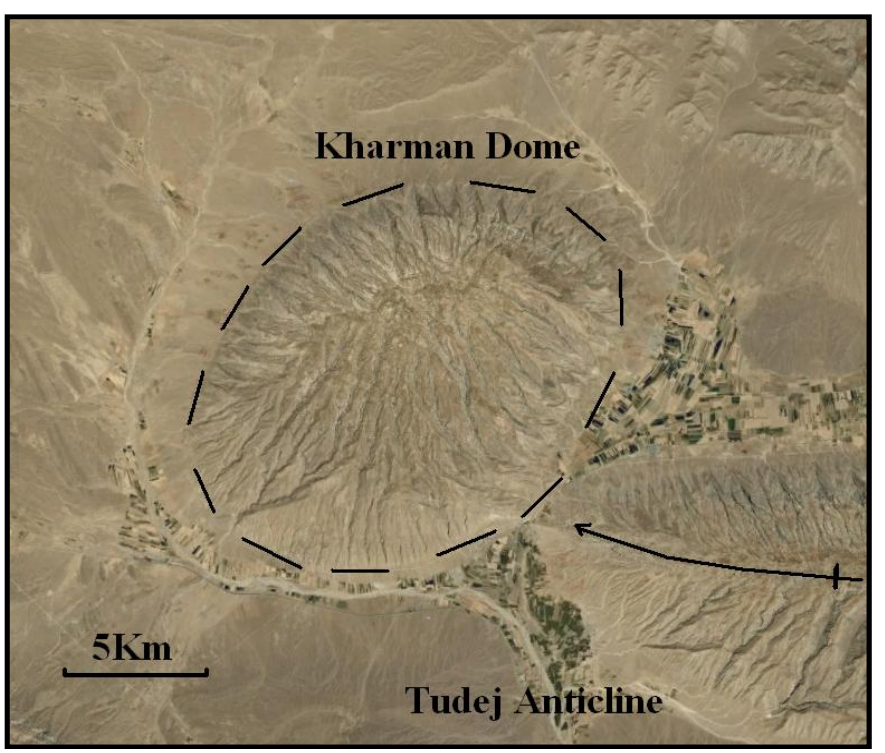

Figure 4. Interpreted ETM+ Satellite Image of Kharman dome. Map located in Figure 1.

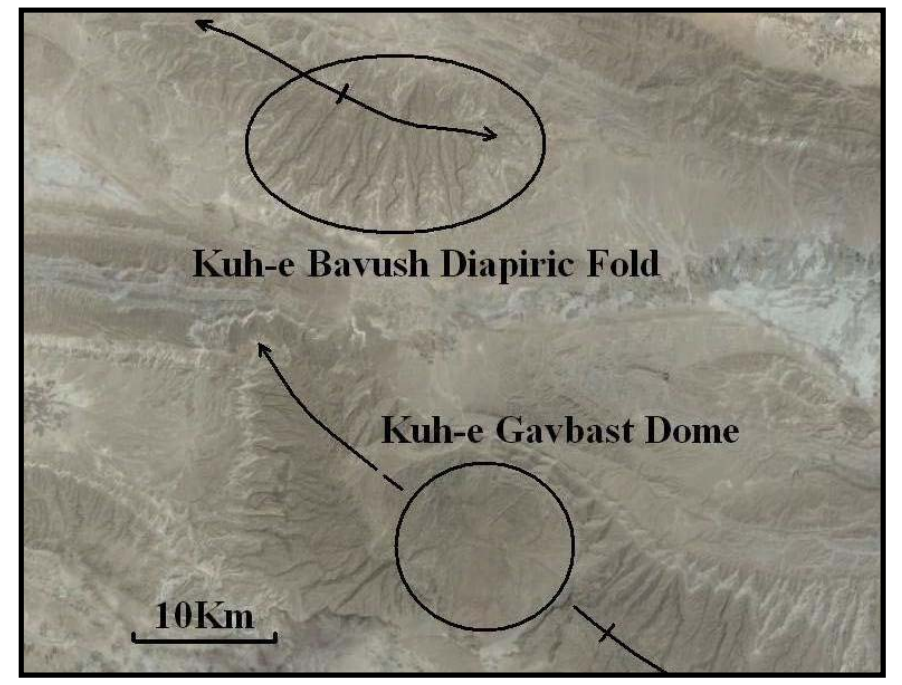

Figure 5. Interpreted ETM+ Satellite Image of Kuh-e Gavbast anticline and diapiric fold such as Kuh-e Bavush in diapiric province of Nyriz-Jahrum. Map located in Figure 1.

\subsection{The Diapiric Province of Shiraz-Kazerun}

The diapiric province of Shiraz-Kazerun is located in the west part of Nyriz-Jahrum diapiric province .It has got twenty three exposed salt diapirs and its area is smaller than Hormuz diapiric province.

The main north-south striking right-lateral faults in Zagros have been controlled location of this salt diapirs such as Kazerun fault with six, Kareh Bas fault [45] [46] with six (Figure 6) and Sarvestan fault with three salt diapirs [47]. It means that they are pre-orogenic salt diapirs, and their positions have been determinate current condition of folds [48] [49]. In addition, salt glacier such as Kuh-e Jahani dome (Figure 7), some blind salt dome such as Gardan anticline and diapiric fold such as Khaftar anticline (Figure 8) are general phenomenon in the Shiraz-Kazerun province.

However, based on previous study [50]-[52] and our investigations on the position, shape and orientation of salt domes in Zagros, three diapiric provinces have been introduced. Salt diapirism of these provinces has been 


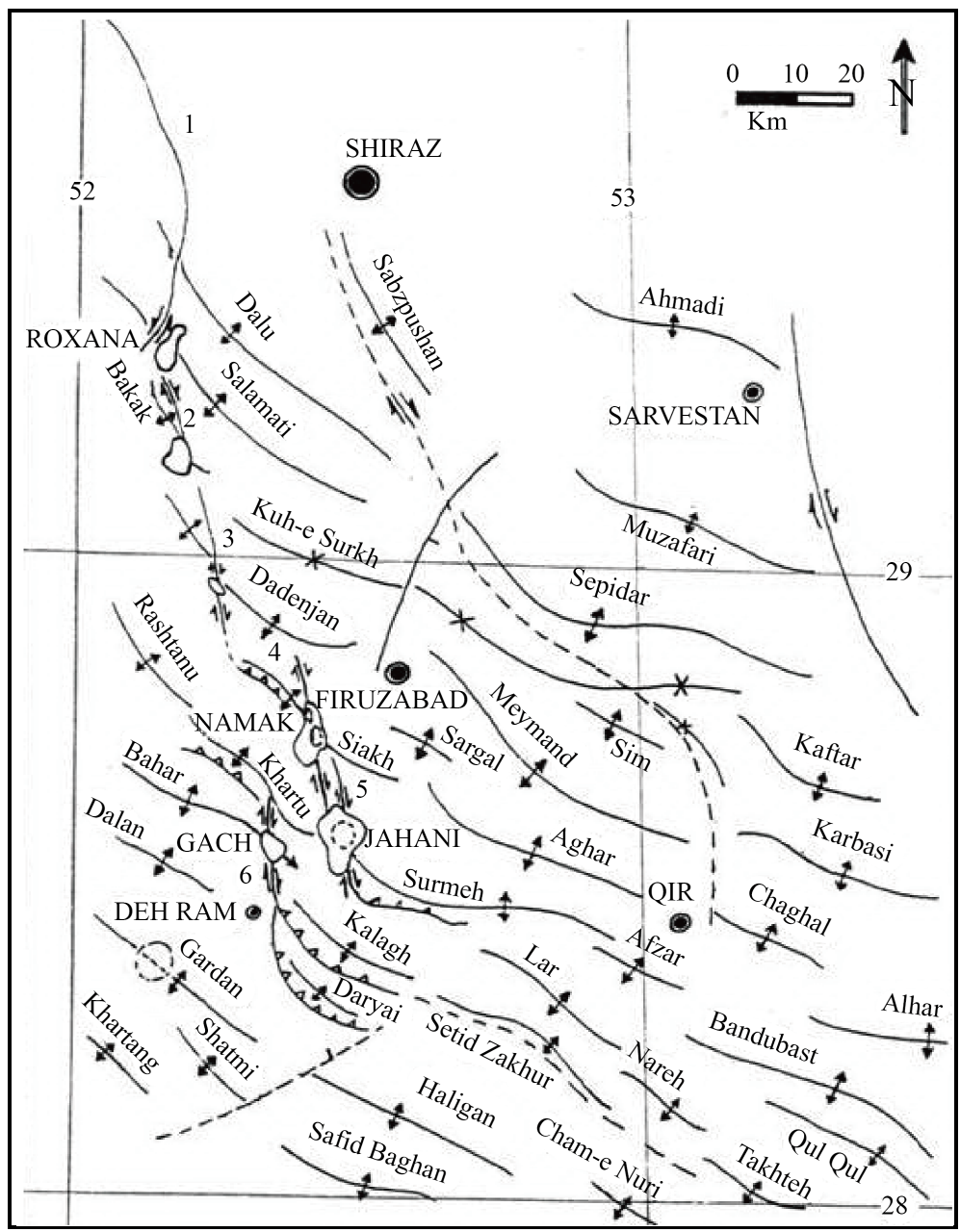

Figure 6. Structural map in a part of Shiraz-Kazerun province. Map located in Figure 1.

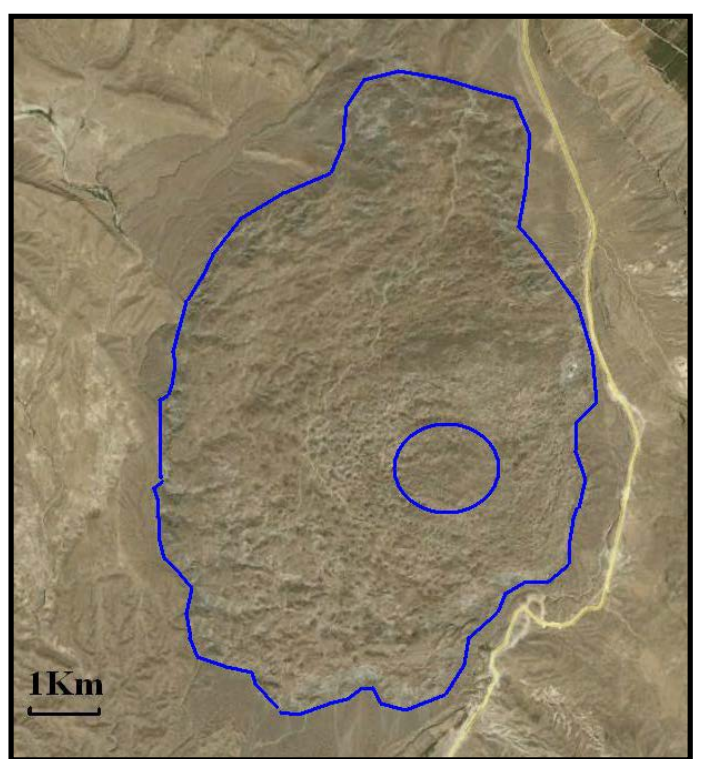

Figure 7. Interpreted ETM+ Satellite Image of Kuh-e Jahani salt glacier. Map located in Figure 1. 
affected by rift development during Paleozoic that it has accompanied with sedimentation of Banded Iron Formation (BIF) in Hormuz Group (Figure 9) on Zagros basin.

Finally, based on previous work on the neotectonic regime in Iran, Zagros in south Iran is the most active zone [53]-[73]. Then, North Iran nd Central Iran [73]-[83] have been situated in the next orders.

\section{Conclusions}

According to our results on the geographic distribution and geological setting of salt plugs in southern Iran, three salt diapiric provinces have been distinguished. These provinces include the Hormuz, Shiraz-Kazerun and Nyriz-Jahrum sub-basins.

Hormuz Salt is a member of the bigger rock unit (Super-group or Group) that, it had been deposited within syn-rift basins of the Arabian basement in Late Proterozoic-Ordovician.

Salt diapirism of these provinces has affected later by tectonic forces (especially in the Zagros hinterland which it has been recorded in orientation, shape and position of salt plugs), although it has been triggered earlier by Halokinesis in the Zagros and Persian Gulf basins. Also, extentional phase of Neo-Tethys rifting at early Paleozoic should be considered as the most important salt diapirism in the southern Iran. This rifting has been an important role on genesis of Banded Iron Formation that introduced in this paper at the first time.

The most of salt plugs are pre-orogenic emergent diapirs, thus they had got essential role in formation and development of the next structures during the Zagros deformation. However, progressive deformation has got an additional affects to reactivation of salt plugs.

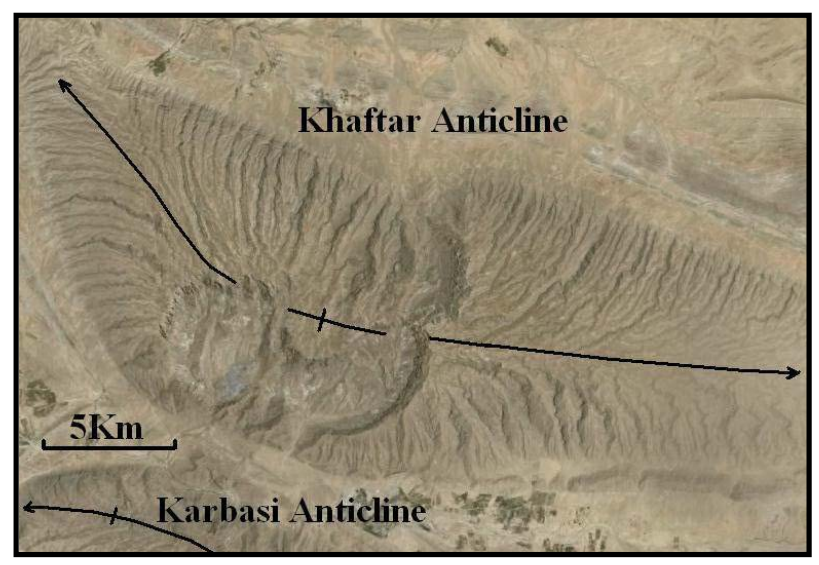

Figure 8. Interpreted ETM+ Satellite Image of Khaftar diapiric fold. Map located in Figure 1.

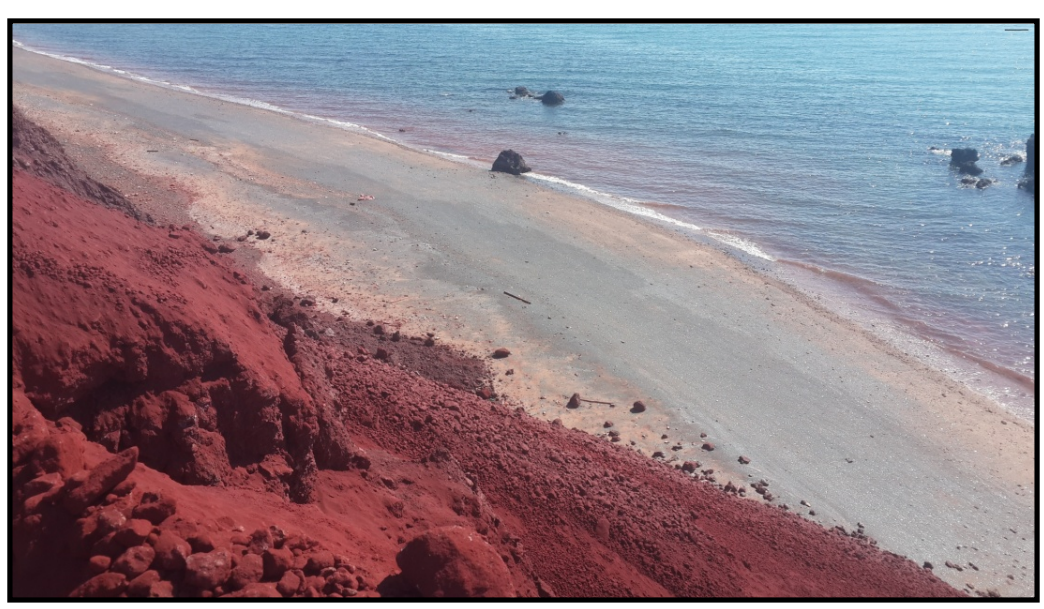

Figure 9. Banded Iron Formation (BIF) in the southern part of Hormuz island. It has been called Ocher or red soil, too. 


\section{Acknowledgements}

The authors acknowledge department of geology, Islamic Azad University, Science and Research branch, Tehran, Iran for funded this project. In addition, we thank Vice-President for Research in Science and Research branch, Tehran.

\section{References}

[1] Asadian, F. and Arian, M. (2009) Identification of Diapiric Provinces of Central Iran through Geological and Geographical Analysis. International Journal of Agriculture Environment \& Biotechnology, 2, 3443-3451

[2] Arian, M. (2012) Clustering of Diapiric Provinces in the Central Iran Basin. Carbonates and Evaporates, 27, 9-18. http://dx.doi.org/10.1007/s13146-011-0079-9

[3] Qorashi, M. and Arian, M. (2011) Tectonics of Iran. Geologic Survey of Iran, 336 p. (In Persian).

[4] Arian, M. (2013) Physiographic-Tectonic Zoning of Iran’s Sedimentary Basins. Open Journal of Geology, 3, 169-177. http://dx.doi.org/10.4236/ojg.2013.33020

[5] Kent, P.E. (1979) The emergent Hormuz salt Plugs of Southern Iran. Journal of Petroleum Geology, 2, 117-144. http://dx.doi.org/10.1111/j.1747-5457.1979.tb00698.x

[6] Edgell, H.S. (1996) Salt tectonics in the Persian Gulf basin. In: Alsop, G.I., Blundell, D.J. and Davison, I., Eds., Salt Tectonics, Special Publication of Geological Society, London, 100, 129-151.

[7] Talbot, C.J. and Alavi, M. (1996) The Past of a Future Syntaxis across the Zagros, In: Alsop, G.I., Blundell, D.J. and Davison, I., Eds., Salt Tectonics, Special Publication of Geological Society, London, 100, 89-109. http://dx.doi.org/10.1144/gsl.sp.1996.100.01.08

[8] Abdollahie Fard, I. (2012) Hormuz Salt in the Abadan Plain (SW Iran). Proceedings of the 30st Symposium on Geosciences, Geological Survey of Iran, 20-22 February 2012, 1-7. (In Persian).

[9] Ahmadzadeh Heravi, M., Houshmandzadeh, A. and Nabavi, M.H. (1990) New Concepts of Hormuz Formation's Stratigraphy and the Problem of Salt Diapirism in South Iran. Proceeding of Symposium on Diapirism, Iran, 1, 1-22. (In Persian).

[10] Mitchell, A.H.G. and Garson, M.S. (1981) Mineral Deposits and Global Tectonic Settings. Academic Press London, $405 \mathrm{p}$.

[11] Motiei, H. (2001) Simplified Table of Rock Unit in South West Iran, a Map Unpublished. KEPS Company.

[12] Stocklin, J. (1968) Salt Deposits of the Middle East. Geological Society of America, Special Issue, 88, 157-181. http://dx.doi.org/10.1130/spe88-p157

[13] Player, R.A. (1969) Salt Diapirs Study. National Iranian Oil Company. Exploration Division, Report No. 1146 (Unpublished).

[14] Huber, H. (1975) Geological Map of Iran 1:1000,000 Scale. NIOC, Exploration and Production.

[15] Verrall, P. (1978) The Significance of Thickness Variations in the Gachsaran Formation. NIOC, Exploration Report 182.

[16] Jahani, S., Callot, J.P., Frizon de Lamotte, D., Letouzey, J. and Leturmy, P. (2007) The Salt Diapirs of the Eastern Fars Province (Zagros, Iran): A Brief Outline of Their Past and Present. Frontiers in Earth Sciences, Springer, 289-308.

[17] Harrison, J.V. (1931) Salt Domes in Persia, Symposium on Salt Domes. Journal of Institute of Petroleum Technology, 17, 300-320.

[18] Ala, M.A. (1974) Salt Diapirism in Southern Iran. AAPG Bulletin, 58, 1758-1770.

[19] Sherkati, S., Molinaro, M., Frizon De Lamotte, D. and Letouzey, J. (2005) Detachment Folding in the Central and Eastern Zagros Fold-Belt (Iran): Salt Mobility, Multiple Detachments and Final Basement Control. Journal of Structural Geology, 27, 1680-1696. http://dx.doi.org/10.1016/j.jsg.2005.05.010

[20] Kent, P.E. (1958) Recent Studies of South Persian Salt Diapirs. AAPG Bulletin, 42, 2951-2972.

[21] Sherkati, S. and Letouzey, J. (2004) Variation of Structural Style and Basin Evolution in the Central Zagros (Izeh Zone and Dezful Embayment), Iran. Marine and Petroleum Geology, 21, 517-640. http://dx.doi.org/10.1016/j.marpetgeo.2004.01.007

[22] Callot, J.P., Jahani, S. and Letouzey, J. (2007) The Role of Pre-Existing Diapirs in Folds and Thrust Belt Development. In: Lacombe, O., Lave, J., Roure, F. and Verges, J., Eds., Thrust Belts and Foreland Basins. From Fold Kinematics to Hydrocarbon Systems, Springer, Berlin, 307-323. http://dx.doi.org/10.1007/978-3-540-69426-7_16

[23] Jahani, S., Callot, J.P., Letouzey, J. and Frizon de Lamotte, D. (2009) The Eastern Termination of the Zagros 
Fold-and-Thrust Belt, Iran: Structures, Evolution, and Relationships between Salt Plugs, Folding and Faulting. Tectonics, 28, 22. http://dx.doi.org/10.1029/2008TC002418

[24] Motiei, H. (1995) Petroleum Geology of Zagros. Geological Survey of Iran Publication, 589 p. (In Persian)

[25] Motamedi, H., Sepehr, M., Sherkati, S. and Pourkermani, M. (2010) Multi-Phase Hormuz Salt Diapirism in the Southern Zagros, SW Iran. Journal of Petroleum Geology, 34, 29-43. http://dx.doi.org/10.1111/j.1747-5457.2011.00491.x

[26] Falcon, N.L. (1967) The Geology of the NE Margin of the Arabian Basement Shield. Advancement of Science, 24, 31-42.

[27] Berberian, M. and King, G.C.P. (1981) Towards a Paleogeography and Tectonic Evolution of Iran. Canadian Journal of Earth Sciences, 18, 210-265. http://dx.doi.org/10.1139/e81-019

[28] Alavi, M. (1994) Tectonics of the Zagros Orogenic Belt of Iran: New Data and Interpretation. Tectonophysics, 229, 211-238. http://dx.doi.org/10.1016/0040-1951(94)90030-2

[29] Arian, M., Pourkermani, M., Sistanipour, A. and Noroozpour, H. (2011) Kinematic Significance of Fold- and FaultRelated Fracture Systems in the Rafsanjan's Northeast Highlands (Central Iran). Journal of Basic and Applied Scientific Research, 1, 3398-3406.

[30] Falvey, D.A. and Middleton, M.F. (1981) Passive Continental Margins: Evidence for a Prebreakup Deep Crustal Subsidence Mechanism. Oceanologica Acta, 4, 103-114.

[31] Alavi, M. (2004) Regional Stratigraphy of the Zagros Fold and Thrust Belt of Iran and Its Proforeland Evolution. American Journal of Science, 304, 1-20. http://dx.doi.org/10.2475/ajs.304.1.1

[32] Ricou, L.E. (1971) Le croissant ophiolitique peri-Arabe: Une ceinture de nappes mises en place au Crétacé superieur. Revue de Geologie Dynamique et de Geographie Physique, 13, 327-350.

[33] Falcon, N.L. (1974) Southern Iran: Zagros Mountains. Geological Society, London, Special Publications, 4, $199-211$. http://dx.doi.org/10.1144/gsl.sp.2005.004.01.11

[34] Arian, M. and Hashemi, A. (2008) Seismotectonic Zoning in the Zagros. Journal of Sciences (Islamic Azad University), 18, 63-76. (In Persian)

[35] Pourkermani, M. and Arian, M. (2001) Structural Geomorphology of Northeastern Kurdistan. Journal of Humanities, 7 , 37-48. (In Persian)

[36] Arian, M. (2010) Earthquake-Fault Hazard Investigations in the Kerman Quadrangle. Journal of Sciences (Islamic Azad University), 19, 176-182. (In Persian)

[37] Khavari, R., Arian, M. and Ghorashi, M. (2009) Neotectonics of the South Central Alborz Drainage Basin, in NW Tehran, N Iran. Journal of Applied Sciences, 9, 4115-4126. http://dx.doi.org/10.3923/jas.2009.4115.4126

[38] Nouri, R., Jafari, M.R., Arian, M., Feizi, F. and Afzal, P. (2013) Correlation between Cu Mineralization and Major Faults Using Multifractal Modelling in the Tarom Area (NW Iran). Geologica Carpathica, 64, 409-416. http://dx.doi.org/10.2478/geoca-2013-0028

[39] Arian, M. and Pourkermani, M. (2004) Tectonic Elements of South Flank in the East-Central Alborz Mountain. Journal of Science (Teacher Training University), 4, 359-368. (In Persian)

[40] Feizi, F., Arian, M. and Rahmani, R. (2007) Seismotectonic Zoning in the Eastern Part of the Central Alborz. Journal of Sciences (Islamic Azad University), 17, 151-164. (In Persian)

[41] Arian, M. Maleki, Z. and Noroozpour, H. (2011) Cenozoic Diastrophism and Deformational Events in the East-Central Alborz. Journal of Basic and Applied Scientific Research, 1, 2394-2400.

[42] Arian, M. and Bagha, N. (2012) Active Tectonics of Tehran Area, Iran. Journal of Basic and Applied Scientific Research, 2, 3805-3819.

[43] Bagha, N., Arian, M., Ghorashi, M., Pourkermani, M., El Hamdouni, R. and Solgi, A. (2014) Evaluation of Relative Tectonic Activity in the Tehran Basin, Central Alborz, Northern Iran. Geomorphology, 213, 66-87. http://dx.doi.org/10.1016/j.geomorph.2013.12.041

[44] Razaghian, G. and Arian, M. (2015) The Emergent Salt Diapirs in the East Zagros, Iran. Open Journal of Geology, 5, 718-726. http://dx.doi.org/10.4236/ojg.2015.510063

[45] Arian, M., Ahmadnia, A., Qorashi, M. and Pourkermani, M. (2002) Structural Analysis of Mengharak Transcurrent Fault System in Zagros, Iran. 5th Middle East Geosciences Conference, 7, 209-210.

[46] Arian, M., Qorashi, M., Pourkermani, M. and Ahmadnia, A. (2006) The Structural Significance Kareh Bas Transcurrent Fault System in the Zagros Fold and Thrust Belt. Geosciences, 15, 126-133 (In Persian)

[47] Arian, M. (2011) A Preface on Salt Tectonics of Iran. Asar-e Nafis Publication, Qom, Iran, 309 p.

[48] Arian, M. (2011) Middle East Tectonics. Asar-e Nafis Publication, Qom, Iran, 236 p. 
[49] Arian, M. (2011) Basement Tectonics and Geology of Iran. Asar-e Nafis Publication, Qom, Iran, 300 p.

[50] Arian, M. and Noroozpour, H. (2015) Tectonic Geomorphology of Iran’s Salt Structures. Open Journal of Geology, 5 , 61-72. http://dx.doi.org/10.4236/ojg.2015.52006

[51] Arian, M. and Noroozpour, H. (2015) The Biggest Salt-Tongue Canopy of Central Iran. Open Journal of Geology, 5, 55-60. http://dx.doi.org/10.4236/ojg.2015.52005

[52] Rahimi, N. and Arian, M. (2014) Tectonic Geomorphplogy of Hamedan-Sosangerd Region, West Iran. Advances in Environmental Biology, 8, 119-124.

[53] Arian, M. and Qorashi, M. (2006) The Movement Potential Evaluation of the Major Quaternary Faults in Alborz-Central Iran Border Zone, from the East of Tehran to the East of Semnan. Journal of Geosciences, Geological Survey of Iran, 15, 184-188.

[54] Gholamhosein Fard, N., Sorbi, A. and Arian, M. (2015) Active Tectonics of Kangavar Area, West Iran. Open Journal of Geology, 5, 422-441. http://dx.doi.org/10.4236/ojg.2015.56040

[55] Arian, M. and Feizi, F. (2005) Application of Geomorphic Indices to the Assessment of Relative Tectonic Activity Levels in the Alborz-Central Iran Border Zone (from the East of Varamin to the East of Semnan). Journal of Sciences (Islamic Azad University), 15, 378-403.

[56] Feizi, F. and Arian, A. (2011) The Role of Structural Controllers in Geneses of Copper Deposits in 1: 50000 Map of Saiin Qaleh. Journal of Sciences, 21, 1-10.

[57] Nouri, R., Jafari, M.R., Arian, M., Feizi, F. and Afzal, P. (2013) Prospection for Copper Mineralization with Contribution of Remote Sensing, Geochemical and Mineralographical Data in Abhar 1:100,000 Sheet, NW Iran. Archives of Mining Sciences, 58, 1071-1084. http://dx.doi.org/10.2478/amsc-2013-0074

[58] Nouri, R., Afzal, P., Arian, M., Jafari, M. and Feizi, F. (2013) Reconnaissance of Copper and Gold Mineralization Using Analytical Hierarchy Process in the Rudbar 1:100,000 Map Sheet, Northwest Iran. Journal of Mining and Metallurgy, 49, 9-19.

[59] Farrokhnia, A.R., Pirasteh, S., Pradhan, B., Pourkermani, M. and Arian, M. (2011) A Recent Scenario of Mass Wasting and Its Impact on the Transportation in Alborz Mountains, Iran Using Geo-Information Technology. Arabian Journal of Geosciences, 4, 1337-1349. http://dx.doi.org/10.1007/s12517-010-0238-7

[60] Arian, M. and Nouri, R. (2015) Lineament Tectonics and Mineralization in Tarom Area, North Iran. Open Journal of Geology, 5, 115-124. http://dx.doi.org/10.4236/ojg.2015.53011

[61] Nouri, R. and Arian, M. (2015) Structural Control on the Distribution of Hydrothermal Alteration Zones and Mineralization in Dastjerdeh Area Based on Remote Sensing Data, NW Iran. Bulletin of the Georgian National Academy of Sciences, 9, 79-86.

[62] Housini Toudeshki, V., Pourkermani, M., Arian, M. and Khosrotehrani, K.H. (2011) Influence of Structures on the Ghezel Ozan River. Geosciences, 21, 55-60.

[63] Housini Toudeshki, V. and Arian, M. (2011) Morphotectonic Analysis in the Ghezel Ozan River Basin, NW Iran. Journal of Geography and Geology, 3, 258-260. http://dx.doi.org/10.5539/jgg.v3n1p258

[64] Arian, M. and Aram, Z. (2014) Relative Tectonic Activity Classification in the Kermanshah Area, Western Iran. Solid Earth, 5, 1277-1291. http://dx.doi.org/10.5194/se-5-1277-2014

[65] Pazhoohan, M., Arian, M., Ghorashi, M. and Khosrotehrani, K. (2014) A Study of Drainage Pattern Responses to Active Tectonics in Tadvan Region, SW Iran. Geodynamics, 1, 36-41.

[66] Arian, M. (2015) Seismotectonic-Geologic Hazards Zoning of Iran. Earth Sciences Research Journal, 19, 7-13. http://dx.doi.org/10.15446/esrj.v19n1.40664

[67] Poroohan, N., Poukermani, M. and Arian, M. (2009) An Assessment on Correlations of Seismotectonic Parameters Preceding and Following Roudbar-Manjil Earthquake (Gilan, North of Iran). Australian Journal of Basic \& Applied Sciences, 3, 2643-2652.

[68] Poroohan, N., Pourkermani, M. and Arian, M. (2013) An Assessment of Relationship in F-Parameter and Paleostress Fields in Heterogeneous Lithologies: Roudbar Area (Northwest of Iran). Australian Journal of Basic \& Applied Sciences, 7, 933-942.

[69] Mardani, Z., Ghorashi, M. and Arian, M. (2011) Geomorphic Signatures of Active Tectonics in the Talaghan Rud, ShahRud and Sefidrud Drainage Basins in Central Alborz, N Iran. Geosciences, 20, 159-166.

[70] Sorbi, A., Arian, M. and Pourkermani, M. (2011) The Application of Geomorphic Indices to the Assessment of Relative Tectonic Activity Levels in Tehran Quadrangle. Journal of the Earth, 6, 1-9.

[71] Khavari, R., Ghorashi, M., Arian, M. and Khosrotehrani, K. (2010) Geomorphic Signatures of Active Tectonics in the Karaj Drainage Basin in South Central Alborz, N, Iran. Geosciences, 19, 67-74. 
[72] Arian, M., Toudeshki, V.H. and Noroozpour, H. (2011) Active Tectonics of Qezel Ozan River Basin, NW Iran. Journal of Applied Environmental and Biological Sciences, 1, 291-295.

[73] Arian, M., Pourkermani, M., Sistanipour, A. and Noroozpour, H. (2011) Seismicity and Fault Segmentation of Bafq-Baghin Fault System (Central Iran). Journal of Applied Environmental and Biological Sciences, 1, 382-396.

[74] Abdideh, M., Qorashi, M., Rangzan, K. and Arian, M. (2011) Assessment of Relative Active Tectonics Using Morphometric Analysis, Case Study of Dez River (Southwestern, Iran). Geosciences, 20, 33-46.

[75] Arian, M., Bagha, N., Khavari, R. and Noroozpour, H. (2012) Seismic Sources and Neo-Tectonics of Tehran Area (North Iran). Indian Journal of Science and Technology, 5, 2379-2383

[76] Arian, M. and Noroozpour, H. (2015) Seismic Activity and Fractal Geometry of Kareh Bas Fault System in Zagros, South of Iran. Open Journal of Geology, 5, 291-299. http://dx.doi.org/10.4236/ojg.2015.55026

[77] Ehsani, J. and Arian, M. (2015) Quantitative Analysis of Relative Tectonic Activity in the Jarahi-Hendijan Basin Area, Zagros, Iran. Geosciences Journal, 19, 751-765. http://dx.doi.org/10.1007/s12303-015-0016-3

[78] Omidali, M., Arian, M. and Sorbi, A. (2015) Neotectonics of Boroujerd Area, SW Iran by Index of Active Tectonics. Open Journal of Geology, 5, 309-324.

[79] Chegini, A., Sorbi, A. and Arian, M. (2015) Active Tectonics of Hamedan Area, West Iran. International Journal of Geography and Geology, 4, 109-128.

[80] Maleki, Z., Arian, M., Solgi, A. and Ganjavian, M.A. (2014) The Elements of Fold Style Analysis in the Khaftar Anticline, Zagros, Iran. Open Journal of Geology, 4, 79-92. http://dx.doi.org/10.4236/ojg.2014.43008

[81] Maleki, Z., Arian, M. and Solgi, A. (2014) Structural Style and Hydrocarbon Trap of Karbasi Anticline, in the Interior Fars Region, Zagros, Iran. Solid Earth Discussions, 6, 2143-2167. http://dx.doi.org/10.5194/sed-6-2143-2014

[82] Ehsani, J., Arian, M. and Ghorashi, M. (2015) Geomorphic Signatures of Active Tectonics in the Jarahi-Hendijan Drainage Basin in the South West Iran. Geosciences, 24, 211-218.

[83] Mashal, M., Kermani, M.P., Charchi, A., Almasian, M. and Arian, M. (2013) Pattern of Structural Geology Underground in Eastern of North Dezfol Embayment. Advances in Environmental Biology, 7, 260-268. 